\title{
How Is Flow Induced? From the Perspective of Online and Offline Channels
}

\author{
Wen-Chin Tsao ${ }^{1} \&$ Yuan-Wei Shao ${ }^{1}$ \\ ${ }^{1}$ Department of Business Administration, National Chin-Yi University of Technology, Taichung, Taiwan, \\ Republic of China \\ Correspondence: Wen-Chin Tsao, No. 57, Sec. 2, Zhongshan Rd., Taiping Dist., Taichung City 41170, Taiwan, \\ Republic of China.
}

Received: November 24, 2017

Accepted: January 2, 2018 Online Published: February 3, 2018

doi:10.5539/ijms.v10n1p11

URL: https://doi.org/10.5539/ijms.v10n1p11

\begin{abstract}
The flourish of internet technology has contributed to the trend of online shopping but also threatened the operation of brick-and-mortar channels. This study investigated how bookstores can use experiential value to influence the repurchase behavior of consumers from the perspective of experiential value. The significant findings of this study are as follows. 1). When channel type is not considered, the experiential values playfulness, escapism, and educational experiences are the most crucial elements for the achievement of flow. 2). Playfulness, educational experiences, and customer return on investment are relatively more important for flow inducement in online channels, while the hedonic experiential values playfulness, escapism, and aesthetics are more prominent in offline channels. This shows that playfulness is an extremely crucial strategic experiential value for bookstores. 3 ). The analysis of moderating effect revealed that aesthetics and service excellence can give brick-and-mortar channels a unique advantage under the threat of online channels. This study included brick-and-mortar channels, unlike past studies that focused on online channels. We believe that the findings, managerial implications, and suggestions in this study are particularly meaningful and valuable for brick-and-mortar stores, which are in gradual decline.
\end{abstract}

Keywords: experiential value, aesthetics, flow, channel type, positive word-of mouth

\section{Introduction}

A survey conducted by the Market Intelligence and Consulting Institute indicated that online consumer spending is increasing annually. From 2014 to 2015, the amount that consumers spent online shopping increased by $27 \%$. Another investigation found that approximately $63 \%$ of all consumers shop at brick-and-mortar stores only, and this percentage has declined by $9 \%$ since 2012 (Chinatimes, 2017). These figures show that online shopping is on a growing trend that threatens the future of brick-and-mortar businesses, including bookstores. Statistics show that approximately 400 bookstores closed between 2007 and 2016, representing a decrease of $15.8 \%$ in Taiwan (United Daily News, 2016). The closing of these bookstores is connected to the changing shopping patterns of consumers. Consumers may go to brick-and-mortar stores to touch and examine the product that they wish to purchase and then order it online because it's convenient and cheaper. This phenomenon is called showrooming (Rapp, Baker, Bachrach, Ogilvie, \& Beitelspacher, 2015), which is equivalent to the oft-mentioned O2O (offline to online) shopping model (Tsao \& Yang, 2017). Managers of businesses with a physical-only presence are attempting to attract consumers into their stores. More importantly, they must find ways to eliminate showrooming so that consumers make purchases directly at their stores. In contrast, businesses with hybrid channels must learn how to cope with $\mathrm{O} 2 \mathrm{O}$ (offline to online or online to offline) shopping models to increase their overall revenue.

Sometimes consumers pursue and attach importance to qualities beyond the actual utility of the product. What matters more to them is whether they have fulfilled their emotional needs during the consumption process (Ellis $\&$ Rossman 2008). From an experience economy perspective, retailers must redefine themselves as the sources of memory rather than sources of goods and become stagers rather than service providers (Pine \& Gilmore, 1999). Consumers' experience emotional resonance when interacting with a business's physical environment; this is a crucial incentive that attracts consumers to revisit (Addis \& Sala, 2007). Many past studies conceptualized value as a trade-off between what consumers gain and lose when buying a product or service 
(Overby \& Lee, 2006; Tsao, 2014). Thus, the measure of value is generally determined by a comparison between cost and benefits (Tsao \& Tseng, 2011; Tsao, 2014). In some cases, the objective of a consumer is not to purchase a product or service but to gain a good shopping experience (Tynan, McKechnie, \& Hartley, 2014). The shopping experience itself can increase the value of the product or service. Senecal, Gharbi, \& Nantel (2002) recommended attracting consumers by incorporating hedonic and utilitarian values into the shopping experience. Wang, Baker, Wagner, \& Wakefield (2007) also found evidence that these two experiential values are important determinants of the future behavioral intentions of consumers.

When a consumer becomes completely immersed in the environmental atmosphere that the retailer provides during the shopping experience, he or she has entered the state of flow. Research on flow in the past mostly focused on how the elements that constitute flow influence online shopping behavior (Novak \& Hoffman, 1997; Lim, 2014; Bridges \& Florsheim, 2008). Recent research on flow examined how the degree of interactivity between brand websites and consumers influences the online flow experience of consumers and how said flow experience in turn impacts their cognitive, affective, and behavior responses (Noort et al., 2012). Most of the studies on experiential value investigated the use of contextual factors in brick-and-mortar stores to create shopping experiences for consumers and influence their future behavioral intentions (Bäckström \& Johansson, 2006; Jin, Line, \& Goh, 2013; Nigam, 2012). Kim \& Thapa (2017) conducted one of the extremely few studies involving perceived value and flow experience; however, their study focused on experience goods in tourism. In view of the decline of brick-and-mortar bookstores and the rise of the $\mathrm{O} 2 \mathrm{O}$ consumption model, this study fills the gaps in previous research by examining experiential value as a antecedent and flow as a strategic mediator.

The C (cognition) - A (affect) - B (behavior) consumer behavior model proposed by Holbrook (1978) has been widely applied by researchers (Tsao, 2014). Experiential value is a feeling formed from the cognition of consumers; flow is an inner emotional response of consumers, and repurchase intention and word-of-mouth are expressions on the behavioral level (Noort et al., 2012; Kim \& Thapa, 2017). Based on the CAB attitude model above, this study established the following research framework: experiential value (hedonic/utilitarian) $\rightarrow$ flow $\rightarrow$ future behavioral intention (repurchase intention/positive word-of-mouth). The subjects of this study were bookstores that suffered significant impact from the online shopping trend. At the same time, the consumption channel (brick-and-mortar/online) served as the moderator of the model as we analyzed the relationships between experiential value and flow, and the relationships between flow and future behavioral intentions. In addition, we examined how these relationships can be applied to the two consumption channels. It is predicted that the results of this study can provide insight into the different experiences that consumers gain from these two consumption channels and confirm which factors induce the state of flow and drive behavioral intentions. We hope that the results can provide managers of both types of businesses with insights into the operational strategies that will help them cope with the new $\mathrm{O} 2 \mathrm{O}$ consumption model.

\section{Literature Review and Hypotheses Development}

\subsection{Flow}

Csikszentmihalyi (1975) described flow as "the holistic sensation that people feel when they act with total involvement". Novak, Hoffman, \& Yung (2000) indicated that flow is used to describe the mental state that people experience when they are deeply involved in an activity. The focus of their awareness narrows, and unrelated perceptions or thoughts are eliminated. This is followed by a loss of the sense of self, the generation of clear goals and responses, and the feeling that they are in control of the environment (Koufaris, 2002). If people derive pleasure from activities and feel free and focused, they will gain intrinsic enjoyment and perceived control and enter the flow state (Landers, Beatty, Wang, \& Mothersbaugh, 2015). Novak et al. (2000) used arousal, challenge, control, focused attention, interactivity, involvement, skill, telepresence, and time distortion as indices to measure flow.

Researchers assert that when consumers perceive hedonic or utilitarian value during their experience, it will stimulate the state of flow (Pelet, Ettis, \& Cowart, 2017). The concept of flow is commonly applied in human-machine or other user interfaces. When a user enters the flow state while using an interface, they feel happy, motivated, and efficient with regard to interface interactions (Shang, Chen, \& Shen, 2005). In a brick-and-mortar retail store, setting up challenges that are beyond the skills of consumers and then providing them with appropriate assistance can help consumers enter the flow state and enhance their shopping experience (Wang \& Hsiao, 2012). When people are immersed in the physical atmosphere, they feel happy, interested, and even excited. These feelings further their immersion in the activity they are engaged in and make them oblivious of themselves. In interface usage, it even influences their learning attitude and quality. In terms of consumer behavior, it affects their future behavioral intentions (Pelet et al., 2017). 


\subsection{Experiential Value}

The experiential value scale developed by Mathwick, Malhotra, \& Rigdon (2001) differentiates hedonic and utilitarian value using extrinsic and intrinsic value. Extrinsic value generally derives from utilitarianist consumers, who pursue shopping benefits with non-sensory attributes like they are aiming to fulfill an objective. Their process resembles the execution of a task or mission (Mathwick et al., 2001; Kim, 2011). In contrast, intrinsic value comes from sensory attributes, such as the sense of entertainment that consumers get from a fun shopping trip (Holbrook, 1996; Mathwick et al., 2001; Kim, 2011; Shobeiri, Mazaheri, \& Laroche, 2014). This study therefore divided experiential value into two types in this study: utilitarian and hedonic.

\subsubsection{Utilitarian Experiential Value}

Utilitarian value derives from a consumer's "conscious pursuit of an intended consequence". It is therefore associated with the execution or completion of a certain task and belongs in the realm of rational perception, e.g., the quality, function, performance, features, and so on (Tsao, 2014; Babin, Darden, \& Griffin, 1994; Bridges \& Florsheim, 2008). Pine \& Gilmore (1998) indicated that in educational experiences, such as attending a class or taking a ski lesson, participants actively absorb information from the external world in an attempt to gain information that will benefit them. Mathwick et al. (2001) categorized service excellence and customer return on investment (CROI) as extrinsic value. This is the experiential value that consumers generate using utilitarian thinking. This study therefore categorized experiential value as originating from an educational experience, service excellence, and CROI as utilitarian values in this study.

During experience processes, educational value prompts participation in activities and enhances learning (Kiili, 2005). Participants must be more proactive so that they can gain new skills or strengthen existing skills via the experience (Williams, 2006). For learners to feel intrinsic value during the learning process and be completely involved, they must perceive an optimal balance between their skills and the challenge they are taking on (Houge Mackenzie, Son \& Hollenhorst, 2014). When there is an optimal balance between skill and challenge, participants become more focused and feel that they have control over the environment, preventing anxiety and boredom and promoting enjoyment and indulgence (Kiili, 2005).

When service meets customer expectations and customers have a positive reaction to service quality, this can be described as service excellence (Choi, 2015). Service excellence also means that service quality reaches the professional level that customers were promised beforehand (Shobeiri et al., 2014). Service excellence can be measured by the judgment and praise that customers give to service providers (Park, Lim, \& Kim, 2013). If online retailers can provide a responsive shopping website that does not disconnect, consumers will feel more immersion and pleasure as they browse the website (Hsu, Chang, \& Chen, 2012). Mobile instant messaging service providers have added many auxiliary functions to instant messaging applications (for example, the app Line originally only offered messaging services but later began providing the latest news, news feed, and electronic payment), allowing users to receive other services without turning to other websites. This increases the perceived usefulness of these applications and helps to enhance focused attention and intrinsic enjoyment (Zhou $\& \mathrm{Lu}, 2011)$. In contrast, if videos on an online video platform keep stuttering, it adversely affects users and prevents them from achieving the state of flow (Staelens et al., 2010). Based on the inferences above, if consumers perceive service excellence, it will facilitate flow.

CROI reflects the extrinsic value of consumers actively using a product or shopping experience to achieve an objective (Park et al., 2013). This includes economic value, the affordability of an offer, and efficiency of the product or service on one side, and the consumer's active investment of financial, temporal, and psychological resources on the other (Mathwick et al., 2001; Shobeiri et al., 2014; Shyu \& Chou, 2015). Utilitarian online shoppers can enter the state of flow mainly due to perceived control, skills, and interaction speed during the shopping process (Bridges \& Florsheim, 2008). Other research has shown that when consumers perceive usefulness, ease of use, a high degree of interaction, and quick responses while using websites, they also perceive focused attention, challenge, and intrinsic enjoyment. Li (2015) also indicated that interaction speed (such as website speed or internet connection speed) has a direct impact on consumer perception of efficiency and value. Greater interaction speeds enable consumers to feel more pleasure and playfulness their interactions with shopping websites.

This study's hypotheses are as follows:

H1: A positive correlation exists between the experiential value of an educational experience and the flow state of consumers. 
H2: A positive correlation exists between the experiential value of service excellence and the flow state of consumers.

H3: A positive correlation exists between experiential value of CROI and the flow state of consumers.

\subsubsection{Hedonic Experiential Value}

Hedonic value in a shopping context includes emotional perceptions such as arousal, heightened involvement, fantasy, and escapism; its attributes include social interaction, entertainment, fun and intrinsic motivation (Bridges \& Florsheim, 2008; Nusair \& Parsa, 2011). Mathwick et al. (2001) categorized aesthetics and playfulness as intrinsic value and posited that intrinsic value is derived from the entertainment brought by the consumption process. Pine \& Gilmore (1998) classified escapism as one of the four realms of an experience. Consumers actively participate in it and pursue their own inner immersion and enjoyable experiences. This study therefore put experiential values such as aesthetics, playfulness, and escapism in the hedonic category.

Aesthetic experiences involve appreciating or enjoying the beauty of an object (Park et al., 2013) and the viewer's overall perception of the physical environment, art, a performance, or a design from a multi-sensory environment of man-made elements or nature. Aesthetic value originates from combining a subject with the environment to create a consistent and harmonious overall manifestation (Jin et al., 2013). Mathwick et al. (2001) defined aesthetics as having two crucial measurement indices: salient visual elements and entertaining or dramatic aspects. An aesthetic experience requires that the viewer focus all of their attention on the target object and generate a satisfying and continuous enjoyment that is inseparable from the activity. For an individual to enter the state of flow while appreciating a work of art, he or she must find personal meaning, unique ideas, feelings, and pleasing visual presentation in the art (Lankford, 2002). An aesthetic experience is an assessment of beauty in people, things, and activities, generated by voluntary or involuntary interactions. When a consumer deeply experiences beauty, he or she becomes absorbed in the activity and everything else becomes insignificant (Augustine \& Zoss, 2006).

The word play comes from the Greek word schole, which means leisure. Play provides an individual with happiness or contentment. Play is considered intrinsic motivation with itself as the objective in the pursuit of immersion in an activity (Unger \& Kernan, 1983). Thus, this experiential value that comes from play is created by the consumers themselves; it is an intrinsic, active, and self-based experience (Keng \& Ting, 2009). When consumers are focused on interactions, they feel curiosity, enjoyment, and fun with regard to the activity; this produces playfulness (Moon and Kim, 2001). A high degree of interactivity in the user interface enhances or changes the user's perception of playfulness and increases the user's perceived control, curiosity, and interest regarding the user interface (Huang, 2003). A research survey regarding workplaces found that when workers who use computers are performing a task, a greater perception of playfulness, challenge and control can help them focus on the activity and enter the flow state (Ghani \& Deshpande, 1994).

Escapism occurs when participants become absorbed in an activity and create a new identity and environment for themselves (Williams, 2006). When participants feel that they have temporarily extracted themselves from their original life during an activity, it means that they have escaped from their daily lives and become immersed in another world (Keng \& Ting, 2009). Verhagen, Feldberg, van den Hooff, Meents, \& Merikivi (2011) indicated that escapism satisfies an individual's cognitive and emotional longings and prompts them to consciously leave reality. Escapism includes a feeling of entertainment that customers generate themselves (Jin et al., 2013). When online game players experience escapism, they are focused and have the ability to control the game environment. Some consumers use shopping to deal with the feelings of boredom or loneliness. Here, the shopping environment becomes a medium by which consumers escape from their daily lives, allowing them to lose their sense of time and gain relief and joy while shopping (Ahmed, Ghingold, \& Dahari, 2007).

This study's hypotheses are as follows:

H4: A positive correlation exists between the experiential value of aesthetics and the flow state of consumers.

H5: A positive correlation exists between the experiential value of playfulness and the flow state of consumers.

H6: A positive correlation exists between the experiential value of escapism and the flow state of consumers.

\subsection{Future Behavioral Intention}

Behavioral intention generally represents customer loyalty; it is a crucial index for the continuity of corporate development and is also used to understand customer retention rates (Chen \& Chen, 2010). This study used repurchase intentions and positive word-of-mouth (WOM) to measure the future behavioral intentions of customers. 


\subsubsection{Repurchase Intention}

Repurchase intention reflects the tendency of a consumer to continue their patronage of a company or purchase a product of the same brand in the future (Ebrahim, Ghoneim, Irani, \& Fan, 2016). If a consumer gains useful or entertaining benefits from a website, it will have a positive impact on their attitude, sense of challenge, concentration, control, and enjoyment with regard to the website. It can also attract, retain, and stimulate the consumer to make another purchase (Hausman \& Siekpe, 2009). While consumers shop, their interactions with webpages affect their degree of involvement, concentration, and enjoyment, which in turn significantly influences their satisfaction, usage intentions, and repurchase intentions (Bilgihan, Okumus, Nusair, \& Bujisic, 2014).

This study therefore developed the following hypothesis:

H7: Consumer flow exerts a significant and positive influence on their repurchase intention.

\subsubsection{Positive Word-of-Mouth}

After consumers use a product or a service, they describe their experiences to other consumers through word of mouth (WOM) (Kuo, Wu, \& Deng, 2009). The American Marketing Association (AMA) (2014) indicated that WOM transfer takes place when people are sharing information regarding products or promotions to their friends. Such information is conveyed between consumers and does not include interaction with manufacturers; WOM does not involve commercial aspects (Tsao, Hsieh, Shih, \& Lin, 2015). In terms of valence, WOM can be positive, neutral, or negative (Tsao, 2014). Söderlund (1998) defined positive WOM as customers telling their friends, relatives, and colleagues about something that they have derived a certain degree of satisfaction from. In other words, if consumers are satisfied during the consumption process, it will prompt the sharing of positive information (Wirtz \& Chew, 2002).

Perceived ease-of-use promotes the perceived control of users over computer interfaces; it arouses their curiosity and captures their attention and interest (Trevino \& Webster, 1992). If consumers can easily use a product or service, they can more easily concentrate on the activity they are engaged in as well as enjoy and become absorbed in it. Thus, flow can help to increase customer satisfaction, loyalty, and the intention to convey positive WOM (Calvo-Porral, Faíña-Medín, \& Nieto-Mengotti, 2017; Drengner, Gaus, \& Jahn, 2008).

Therefore, this study offers the following hypothesis:

H8: Consumer flow exerts a significant and positive influence on the transfer of positive WOM.

\subsection{Channel Type: Online and Offline}

Most consumers shop online for utilitarian purposes. When a consumer seeks to save money or seeks convenience, he or she will generally be inclined to shop online (Overby \& Lee, 2006; Tsao, 2014). Utilitarian value comes from the fact that consumers can easily obtain more information on the internet and find the best price, which is a crucial motive for online shopping (Broekhuizen \& Jager, 2004). When consumers shop for utilitarian purposes, they will more actively search for lower prices so as to more efficiently allocate their funds. Online shopping has therefore become a crucial shopping channel for this group of consumers. In contrast, consumers with hedonic motivation tend to shop at brick-and-mortar stores (Scarpi et al., 2014). Research has shown that consumers with hedonic motivation or experiential tendencies shop online less frequently. It is speculated that this is because they cannot feel the atmosphere of online channels that they would otherwise feel at brick-and-mortar stores (Li, Kuo, \& Rusell, 1999). This shows that the shopping motivation of consumers will also affect which shopping channels they prefer. Thus, the influence that utilitarian or hedonic experiential value exerts on flow will naturally vary with the type of shopping channel.

WOM requires that consumers personally use a product and then share their assessments and opinions of the product. For this reason, the sensory experiences that brick-and-mortar stores provide become extremely important when consumers cannot ascertain the attributes of a product or are not sure what brand they want. Wang, Ho, \& Chen (2015) discovered that experiential marketing is more conducive to brand image promotion and positive WOM transfer when done in brick-and-mortar channels rather than in virtual channels. Related research has also shown that if a firm has both online and offline channels, the shopping experiences gained in the brick-and-mortar channel can indirectly influence a consumer's trust in the virtual channel and his or her willingness to recommend it (Verhagen \& Van Dolen, 2009). Furthermore, whether it is the virtual channel or the brick-and-mortar channel, the attitude that consumers have towards a store exerts a positive impact on their purchase intentions. Nevertheless, for certain products, the risk of purchasing online is greater than purchasing it at a brick-and-mortar store, so consumers may still prefer to see the actual product at a brick-and-mortar store before deciding whether they want to purchase it (Chu, Wu, Wu, \& Chen, 2017). 
Based on the inferences above, this study holds that brick-and-mortar stores provide more sensory experiences such as taste, sound, and touch and therefore are more able to attract consumers into the environments set up by retailers. As a result, we predict that the hedonic experiential values of aesthetics, playfulness, and escapism are more conducive to flow for offline shoppers than online shoppers. In contrast, the utilitarian experiential values of educational experiences, service excellence, and CROI are likely to have a greater positive influence on flow in online channels than in offline channels. Finally, even though both online and offline channels generate positive WOM and repurchase behavior, consumers are likely to be more loyal to offline channels because they trust the brand images of offline channels more. This loyalty then indirectly influences their behavioral intention toward the online channel of the same brand. Thus, this study posits that the influence of consumer flow on future behavioral intention is greater for offline shoppers than online shoppers.

Therefore, this study offers the following hypotheses:

H9a-c: The positive influence of the utilitarian experiential values of (a) educational experiences, (b) service excellence, and (c) CROI on flow is more significant in online shoppers than in offline shoppers.

H9d-f: The positive influence of the hedonic experiential values of (d) aesthetics, (e) playfulness, and (f) escapism on flow is more significant for offline shoppers than online shoppers.

H9g: The positive influence of flow on repurchase intention is more significant for offline shoppers than online shoppers.

H9h: The positive influence of flow on positive WOM is more significant for offline shoppers than online shoppers.

Figure 1 illustrates the conceptual model developed by this study based on the aforementioned literature and hypotheses.

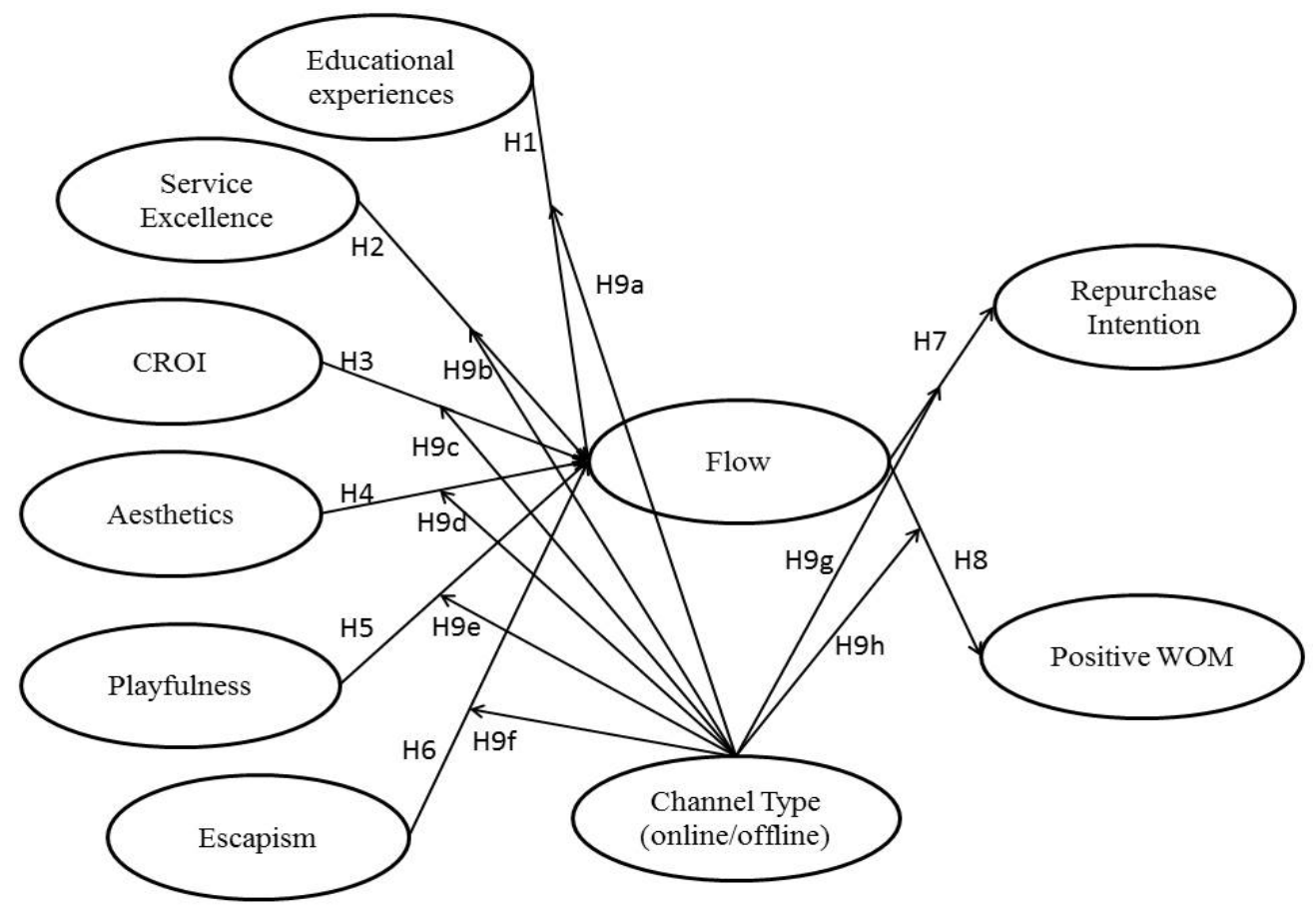

Figure 1. Conceptual research model

\section{Methods}

\subsection{Development of Measures}

We first define the six constructs of the antecedent experiential value in our model. Educational experiences refer to consumption and experience processes during which customers perceive that they have broadened their own knowledge and skill (Shellman, 2014). Service excellence is the consumer perception that the service provided by service providers is excellent and superior (Mathwick et al., 2001). CROI is the consumer perception that 
they have received a return of economic value or efficiency with their purchase (Mathwick et al., 2001). Aesthetics is the feeling that a store's interior and exterior design is appealing, interesting, or comfortable (Mathwick et al., 2001; Jin et al., 2013). Playfulness comes from when consumers perceive fun, entertainment, and intrinsic enjoyment during the consumption process (Mathwick et al., 2001; Keng \& Ting, 2009). Escapism is the feeling that consumers get during consumption processes that they can escape real life and forget their worries (Mathwick et al., 2001; Jin et al., 2013). Flow is defined as the state of customers achieving intrinsic enjoyment, control, and concentration during the consumption process (Landers et al., 2015). Repurchase intention is the possibility that the customer will continue their patronage in the future (Hicks, Page Jr, Behe, Dennis, \& Fernandez, 2005). Positive WOM is the positive reviews that customers share and their recommendations of a company or product (Tsao et al., 2015). The nine constructs above contained a total of 34 question items, each measured using a seven-point Likert scale ranging from 1 as strong disagreement to 7 as strong agreement. Question content and related references are provided in Appendix A.

The moderator in the model was channel type. Based on literature, we divided bookstore channels into online channels and offline channels. Any use of global information infrastructure (i.e., internet communication equipment) comprising electronic software and hardware to sell books, magazines, or stationery was referred to as an online channel, whereas the selling of goods via brick-and-mortar stores rather than via internet facilities was referred to as an offline channel (Peterson, Balasubramanian, \& Bronnenberg, 1997).

\subsection{Data Collection and Sample Profile}

The participants of this study were chosen via convenience sampling and comprised people who had made a purchase at an online or brick-and-mortar bookstore with the previous year. Considering that the topic involves the internet, we administered our questionnaire via online social networking platforms (Facebook and Luckydog) At the beginning of the questionnaire, the participants were asked whether they had made a purchase at an online or brick-and-mortar bookstore with the previous year and whether it was an online or brick-and-mortar bookstore. With these two questions, we chose participants that fit our criteria. We received a total of 548 questionnaires; after the invalid questionnaires were eliminated, 332 valid samples remained. Hair, Anderson, Tatham, \& Black (1998) mentioned that the sample size for an SEM analysis be at least five times (or better, ten times) as large as the estimated parameters being analyzed in the model. With 332 valid samples, this study satisfied the requirement that Hair's suggestion.

In terms of gender, 109 participants were male (32.8\%), and 223 participants were female (67.2\%). The largest age group comprised 192 participants (57.8\%) between the ages of 21 and 30, and the second largest group contained 73 participants $(22.0 \%)$ under the age of 20 . With regard to educational background, the majority, that is, 222 participants $(66.9 \%)$, had a bachelor's degree, while 92 participants $(27.7 \%)$ had a master's degree. In occupation, students occupied the largest proportion, accounting for 201 participants $(60.5 \%)$, while 35 participants $(10.5 \%)$ worked in the service industry. In consumption frequency, 119 participants $(35.8 \%)$ made one purchase per month, and 96 participants $(28.9 \%)$ made one purchase every three months. The vast majority (273 participants; $82.2 \%$ ) spent under NTD 1,000 per purchase, while 47 participants $(14.2 \%)$ spend between NTD 1,001 and NTD 2,000 per purchase.

\section{Analysis and Results}

\subsection{Reliability and Validity}

Afterwards, confirmatory factor analysis (CFA) was applied on the verification of the unidimensionality of each construct (Anderson \& Gerbing, 1988). As shown in Table 1, all Cronbach's alpha estimates are greater than 0.7, ranging from 0.863 to 0.949 . The figures for composite reliability $\left(\rho_{c}\right)$ are all greater than 0.6 , indicating that every construct meets the requirement for internal consistency (Fornell, 1992; Nunnally \& Bernstein, 1994).

Construct validity was verified by convergent validity and discriminant validity. In Table 1 , the measurement properties of the nine constructs shows that the factor loadings (lambdas) are greater than 0.5 and statistically significant (the t-values for the factor loadings ranged from 13.423 to 27.847 , exceeding 2 ), satisfying the criteria for convergent validity (Hair rt al., 1998; Simonin, 1999). When the shared variance among any two constructs (i.e., the square of their intercorrelation) is less than the AVE of each construct, the discriminant validity is assured (Fornell \& Larcker, 1981). In Table 2, the AVE of the underlying construct is higher than their shared variance with other constructs. Therefore, the nine constructs demonstrate discriminant validity. 
Table 1 . The reliability and validity analysis for the constructs

\begin{tabular}{|c|c|c|c|c|c|c|c|c|}
\hline Construct & $\begin{array}{l}\text { Measured } \\
\text { Item }\end{array}$ & Mean & $\begin{array}{l}\text { Standard } \\
\text { deviation } \\
\text { (S.D.) }\end{array}$ & $\begin{array}{l}\text { Standardized } \\
\text { loading }\end{array}$ & $t$-value & $\begin{array}{l}\text { Composite } \\
\text { reliability }\end{array}$ & $\begin{array}{l}\text { Cronbach's } \\
\text { alpha }\end{array}$ & AVE \\
\hline \multirow{4}{*}{$\begin{array}{l}\text { Educational } \\
\text { experiences (ED) }\end{array}$} & ED1 & 5.605 & 0.985 & 0.840 & --- & \multirow{4}{*}{0.937} & \multirow{4}{*}{0.908} & \multirow{4}{*}{0.787} \\
\hline & ED2 & 5.509 & 1.073 & 0.916 & 17.845 & & & \\
\hline & ED3 & 5.467 & 1.072 & 0.910 & 17.102 & & & \\
\hline & ED4 & 5.316 & 1.168 & 0.880 & 16.181 & & & \\
\hline \multirow{4}{*}{$\begin{array}{l}\text { Service } \\
\text { (SE) }\end{array}$} & SE1 & 5.298 & 1.048 & 0.860 & --- & \multirow{4}{*}{0.941} & \multirow{4}{*}{0.917} & \multirow{4}{*}{0.801} \\
\hline & SE2 & 5.368 & 1.090 & 0.926 & 19.069 & & & \\
\hline & SE3 & 5.084 & 1.093 & 0.898 & 17.301 & & & \\
\hline & SE4 & 5.352 & 1.099 & 0.896 & 17.333 & & & \\
\hline \multirow{3}{*}{$\begin{array}{l}\text { CROI } \\
(\mathrm{CR})\end{array}$} & CR1 & 5.253 & 1.175 & 0.880 & --- & \multirow{3}{*}{0.943} & \multirow{3}{*}{0.906} & \multirow{3}{*}{0.846} \\
\hline & CR2 & 5.455 & 1.086 & 0.941 & 18.719 & & & \\
\hline & CR3 & 5.437 & 1.034 & 0.938 & 18.498 & & & \\
\hline \multirow{3}{*}{ Aesthetics (AE) } & $\mathrm{AE} 1$ & 5.485 & 1.141 & 0.920 & - & \multirow{3}{*}{0.957} & \multirow{3}{*}{0.932} & \multirow{3}{*}{0.881} \\
\hline & AE2 & 5.395 & 1.186 & 0.948 & 23.803 & & & \\
\hline & AE3 & 5.370 & 1.211 & 0.947 & 23.879 & & & \\
\hline \multirow{3}{*}{ Playfulness (PL) } & PL1 & 5.494 & 1.405 & 0.916 & - & \multirow{3}{*}{0.944} & \multirow{3}{*}{0.911} & \multirow{3}{*}{$0.84 \mathrm{C}$} \\
\hline & PL2 & 5.440 & 1.360 & 0.947 & 24.410 & & & \\
\hline & PL3 & 5.175 & 1.303 & 0.901 & 19.855 & & & \\
\hline \multirow{4}{*}{ Escapism (ES) } & ES1 & 4.702 & 1.383 & 0.921 & --- & \multirow{4}{*}{0.963} & \multirow{4}{*}{0.949} & \multirow{4}{*}{0.868} \\
\hline & $\mathrm{ES} 2$ & 4.684 & 1.491 & 0.947 & 26.957 & & & \\
\hline & ES3 & 4.762 & 1.491 & 0.950 & 27.583 & & & \\
\hline & ES4 & 4.973 & 1.469 & 0.910 & 22.996 & & & \\
\hline \multirow{3}{*}{ FL1 } & FL11 & 5.286 & 1.099 & 0.903 & --- & & & \\
\hline & FL12 & 5.190 & 1.178 & 0.959 & 22.787 & 0.954 & 0.928 & 0.874 \\
\hline & FL13 & 5.229 & 1.185 & 0.942 & 21.688 & & & \\
\hline Flow & FL21 & 5.494 & 1.159 & 0.946 & --- & & & \\
\hline$(\mathrm{FL})$ & FL22 & 5.452 & 1.113 & 0.947 & 27.847 & 0.965 & 0.945 & 0.902 \\
\hline & FL23 & 5.500 & 1.167 & 0.956 & 30.506 & & & \\
\hline & FL31 & 5.551 & 1.249 & 0.941 & - & & & \\
\hline FL3 & FL32 & 5.630 & 1.033 & 0.941 & 22.029 & 0.940 & 0.863 & 0.886 \\
\hline Repurchase & RP1 & 5.777 & 1.104 & 0.943 & - & 0941 & 0873 & 0880 \\
\hline intention (RP) & $\mathrm{RP} 2$ & 5.913 & 0.993 & 0.943 & 13.423 & 0.941 & 0.873 & 0.889 \\
\hline & PW1 & 5.476 & 1.195 & 0.933 & --- & & & \\
\hline $\begin{array}{l}\text { positive WOIM } \\
\text { (PW) }\end{array}$ & PW2 & 5.449 & 1.227 & 0.922 & 22.571 & 0.943 & 0.910 & 0.846 \\
\hline$(\mathrm{PW})$ & PW3 & 5.419 & 1.195 & 0.906 & 20.040 & & & \\
\hline
\end{tabular}

Table 2. Fornell/Larcker criterion for the nine constructs.

\begin{tabular}{llllllllll}
\hline Construct & ED & SE & CR & AE & PL & ES & FL & RP & PW \\
\hline ED & 0.787 & & & & & & & & \\
SE & 0.224 & 0.800 & & & & & & & \\
CR & 0.042 & 0.184 & 0.846 & & & & & & \\
AE & 0.262 & 0.284 & 0.091 & 0.881 & & & & & \\
PL & 0.288 & 0.282 & 0.021 & 0.387 & 0.849 & & & & \\
ES & 0.291 & 0.306 & 0.026 & 0.335 & 0.510 & 0.868 & & & \\
FL & 0.434 & 0.355 & 0.107 & 0.424 & 0.445 & 0.514 & 0.731 & & \\
RP & 0.117 & 0.255 & 0.204 & 0.170 & 0.089 & 0.102 & 0.240 & 0.889 & \\
PW & 0.124 & 0.368 & 0.214 & 0.219 & 0.181 & 0.198 & 0.296 & 0.398 & 0.846 \\
\hline
\end{tabular}

Note. ${ }^{a}$ Average variance extracted on diagonal; the square of their intercorrelation below the diagonal.

\subsection{The Fitness of the Structural Model and Hypotheses Tests}

The structural equation modeling (SEM) was applied to estimate the parameters of the structural model shown in Figure 1, and the completely standardized solutions computed by the Amos 21 maximum-likelihood method. The fit indices of our study model included $\chi_{(332)}^{2}=1408.883, \mathrm{df}=501, \chi^{2} / \mathrm{df}=2.812$, IFI $=0.922$, TLI $=0.912$, $\mathrm{CFI}=0.921$, and RMSEA $=0.074$, as shown in Table 3. Researchers define a good fit as a TLI no less than 0.8 , 
RMSEA no greater than 0.08, or CFI no less than 0.9 (Hooper, Coughlan, \& Mullen, 2008). Lambert, Hogan, \& Barton (2001) also suggested that $\chi^{2} /$ d.f. be less than 3 and IFI be greater than 0.9. According to the suggestions above, the study model has a good fit and good explanatory power.

As shown in Table 3, the three utilitarian experiential values (educational experiences, service excellence and CROI) and the three hedonic experiential values (aesthetics, playfulness and escapism) exert significant and positive influence on flow. Thus, H1, H2, H3, H4, H5, and $\mathrm{H} 6$ are all supported. This result shows that if consumers can perceive rational value from their consumption experiences, such as gaining new knowledge or skills, perceiving excellent service quality, or feeling that they have picked up a bargain, it will help consumers achieve flow. Furthermore, if consumers can perceive multiple sensory and emotional perception values from the product or environment, such as visual enjoyment, fun interactive designs, and an atmosphere that can help them escape reality, it will promote flow in consumers. Playfulness is the most significant in this respect, followed by escapism and then educational experiences.

The results in Table 3 also indicate that flow has a significant and positive impact on repurchase intention and positive WOM. This study thus infers that greater flows experienced during bookstore shopping will induce greater willingness to return in consumers and prompt them to share comments favorable to the bookstore to others. As a result, $\mathrm{H} 7$ and $\mathrm{H} 8$ are supported as well.

Table 3. Structural parameter estimates and goodness-of-fit indices

\begin{tabular}{lllll}
\hline Hypothesis & Path & $\begin{array}{l}\text { Standardized } \\
\text { coefficient }\end{array}$ & $\begin{array}{l}t \text {-value } \\
\text { (S.E.) }\end{array}$ & Result \\
\hline $\mathrm{H} 1$ & $\begin{array}{l}\text { Educational } \\
\text { experiences } \rightarrow \text { Flow }\end{array}$ & $0.220^{* * *}$ & $4.802(0.040)$ & Supported \\
\hline $\mathrm{H} 2$ & $\begin{array}{l}\text { Service Excellence } \\
\rightarrow \text { Flow }\end{array}$ & $0.167^{* * *}$ & $3.323(0.041)$ & Supported \\
\hline $\mathrm{H} 3$ & CROI $\rightarrow$ Flow & $0.139^{* * *}$ & $3.591(0.029)$ & Supported \\
\hline H4 & Aesthetics $\rightarrow$ Flow & $0.170^{* * *}$ & $3.509(0.034)$ & Supported \\
\hline H6 & Playfulness $\rightarrow$ Flow & $0.243^{* * *}$ & $4.027(0.034)$ & Supported \\
\hline H7 & Escapism $\rightarrow$ Flow & $0.232^{* * *}$ & $4.137(0.031)$ & Supported \\
\hline H8 & $\begin{array}{l}\text { Flow } \rightarrow \text { Repurchase } \\
\text { Intention }\end{array}$ & $0.582^{* * *}$ & $9.027(0.098)$ & Supported \\
\hline & $\begin{array}{l}\text { Flow } \rightarrow \text { Positive } \\
\text { WOM }\end{array}$ & $0.655^{* * *}$ & $9.846(0.103)$ & Supported \\
\hline
\end{tabular}

Fit indices: $\chi^{2}{ }_{(332)}=1408.883 ;$ d.f. $=501 ; \chi^{2} /$ d.f. $=2.812 ; \mathrm{IFI}=0.922 ; \mathrm{TLI}=0.912 ; \mathrm{CFI}=0.921 ; \mathrm{RMSEA}=0.074$

Note. ${ }^{*} p<0.05 ;{ }^{* *} p<0.01 ;{ }^{* * *} p<0.001$.

\subsection{The Analysis of Moderating Effect}

This study used the multiple-group analysis to examine the moderating effects of channel type on the conceptual model in Figure 1. The samples in this study were divided into two groups: consumers that had purchased goods at online bookstores $(n=174)$ and consumers that had made purchases at brick-and-mortar, or offline, bookstores $(\mathrm{n}=158)$. In this study, the $\chi^{2}$ difference was formulated by individually constraining suitable pairs of $\beta$ estimates so as to ensure equivalence between the groups, thus determining as to whether chi-square values changed significantly in one degree of freedom $\left(\chi^{2}=3.84, \mathrm{df}=1, \alpha=0.05\right)$ (Bagozzi \& Heatherton, 1994). Because the $\chi^{2}$ difference $\left(\Delta \chi^{2}\right)$ exceeds 3.84 , it is suggested that the difference between the coefficients of the two groups reached the level of significance (Tsao \& Chen, 2011).

The estimates coefficients and goodness-of-fit indices, which are used in the two-group comparison, are presented in Table 4. First, we analyzed the correlation between flow and the utilitarian aspect of experiential value in the two channel types. The results in Table 4 indicate that the positive influences of educational experiences and CROI on flow are statistically significant in both groups, and the path coefficients also show that the influences are greater in online channels than in offline channels. However, multiple-group tests indicated that the difference between the two groups was not significant $\left(\left|\Delta \chi^{2}\right|<3.84\right)$, which means that H9a and H9c are not supported. The positive influence of service excellence on flow was not significant in online channels $\left(\beta_{\text {online, } \mathrm{SE} \rightarrow \mathrm{FL}}=0.145\right)$ but was significant in offline channels $\left(\beta_{\text {offline, } \mathrm{SE} \rightarrow \mathrm{FL}}=0.200^{* *}\right)$. This means that the influence of service excellence on flow is greater in offline channels than in online channels. The results indicate the opposite of our hypothesis, so H9b is not supported. 
We next analyzed interferences in the relationship between flow and the hedonic aspect of experiential value. The positive influence of aesthetics on flow was significant in offline channels $\left(\beta_{\text {offline, } \mathrm{AE} \rightarrow \mathrm{FL}}=0.217^{* *}\right)$ but not significant in online channels $\left(\beta_{\text {online, } \mathrm{AE} \rightarrow \mathrm{FL}}=0.050\right)$. Thus, $\mathrm{H} 9 \mathrm{~d}$ is supported. The results in Table 4 similarly show that while the positive influences of playfulness and escapism are statistically significant in both groups, multiple-group tests indicated that the difference between the two groups was not significant. Consequently, H9e and H9f were not supported. Finally, although the positive impact of flow on repurchase intention and positive WOM was greater in offline channels than in online channels, multiple-group tests indicated that the difference between the two groups was not significant. Thus, $\mathrm{H} 9 \mathrm{~g}$ and $\mathrm{H} 9 \mathrm{~h}$ were not supported.

Table 4. The results of testing moderating effects of channel type

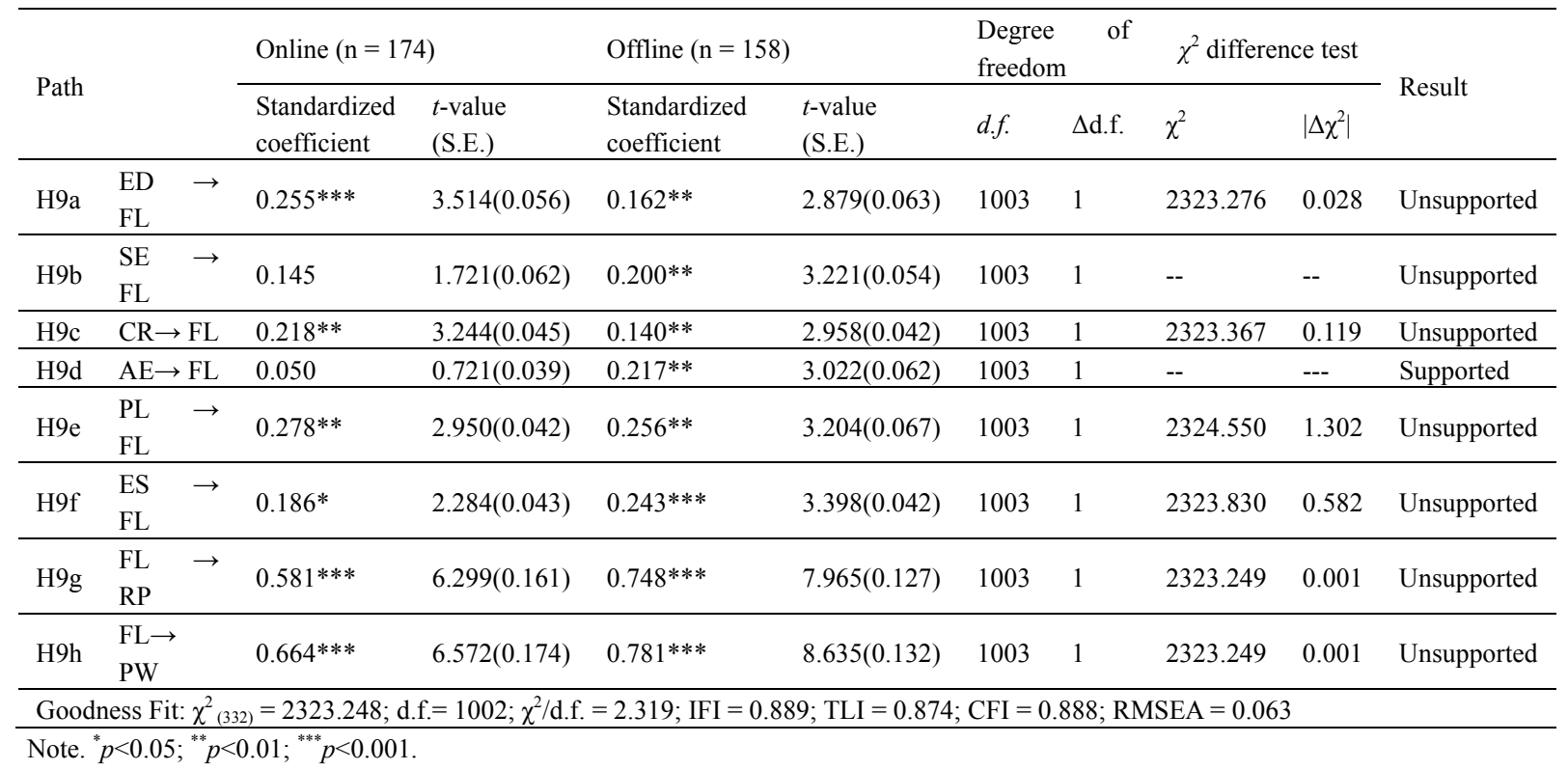

\section{Discussion}

\subsection{Summary of Findings}

This study combined the value theories of Pine \& Gilmore (1998) and Mathwick et al. (2001) to determine how experiential value induces the flow proposed by Csikszentmihalyi (1975) and how flow influences the subsequent behavior of consumers. This study also examined the changes in these causal paths in the two types of channels.

When we look at both channels, both utilitarian and hedonic experiential values exert significant and positive impact on the inducement of flow. In the utilitarian aspect, consumers can achieve flow more easily when they feel that shopping around a store brings them more knowledge or skills, perceive greater service quality from service personnel, and feel that they have picked up a bargain. What is noteworthy is that the influence of educational experiences was the most prominent. Next, in the hedonic aspect, consumers can achieve flow more easily when they feel that a bookstore's décor or webpage design is visually aesthetic and can feel entertained or escape from reality. The influences of playfulness and escapism were the most significant. Furthermore, this study also confirmed the importance of flow to the repurchase intention and positive WOM dissemination of consumers. In other words, if stores could create various atmospheres that can help consumers feel focused and in control while immersed in the store environment and perceive enjoyment at the same time, it will significantly increase the subsequent behaviors of consumers (Landers et al., 2015; O'Cass \& Carlson, 2010).

When we look at the two channel types separately, the influence of educational experiences and CROI on flow show no significant differences in the two channels, which means that these two experiential values are of equal importance in the inducement of flow. In contrast, the influence of service excellence on flow was significantly greater in offline channels than in online channels, which was the opposite of our hypothesis. This implies that online shoppers are not as demanding as brick-and-mortar store shoppers when it comes to service quality (Maghnati \& Ling, 2013). With this finding, this study seems to have found the means of highlighting the advantages of brick-and-mortar channels and a strategic tool to set them apart from online channels. 
As expected, the influence of aesthetics on flow is significantly greater in offline channels than in online channel. Thus, if consumers want visual enjoyment from the environment and a feast for the eyes with an intriguing or dramatic display, they must go to a brick-and-mortar store to fulfill this desire. The positive influences of playfulness and escapism on flow presented significant differences in the two channel types, which similarly implies that these two experiential values are of equal importance to inducing and enhancing consumer concentration and perceived control (C,elik, 2010; Keng, Huang, Zheng, \& Hsu, 2007). Finally, we found that the positive influence of flow on repurchase intention and positive WOM is equally crucial in both online and offline channels. With electronic WOM (eWOM) being prevalent nowadays (Tsao, 2014; Tsao et al., 2015, Tsao \& Hsieh, 2015), this finding is worth more attention from managers.

Unfortunately, the hypotheses that channel type moderates the causal paths of our study model were not sufficiently supported. This study speculates that to prevent being replaced by online bookstores, brick-and-mortar bookstores constantly launch a variety of promotional activities, improve the educational experience design of the store environment, and enhance service quality so that consumers will perceive more utilitarian benefits. Furthermore, advances in internet technology (such as virtual or augmented reality) enable them to offer hedonic benefits (playfulness and escapism) that can only be experienced in a physical environment, and then invest in or reinforce the virtual environment. Based on these two speculations, this study believes that the difference in the ways in which experiential value promotes flow in these two channel types has become smaller. Even so, current technology means that it remains difficult for online channels to replace offline channels in terms of aesthetics.

In conclusion, the experiential values playfulness, escapism, and educational experiences are the most crucial elements for the achievement of flow when channel type is not considered. Playfulness, educational experiences, and CROI are relatively more important for flow inducement in online channels, while the hedonic experiential values playfulness, escapism, and aesthetics are more prominent in offline channels. Furthermore, this study found that playfulness is an extremely crucial strategic experiential value, which we will discuss in more detail later.

\subsection{Managerial Implications and Contributions}

As mentioned above, playfulness is the most important experiential value in both online and offline channels. Brick-and-mortar bookstores can aim at creating a fun and happy atmosphere for consumers. In marketing communication activities, they can establish more interactions between consumers and the vender end, which includes publishers, authors, or store personnel, and even technology-based communication media (such as robots, smartphone apps, or QR codes (Tsao \& Yang, 2017). This study believes that technological interaction media can prompt consumers to create more self-based and interesting experiences. Online bookstores can enrich their webpage platform by adding interactive games or links to jokes (Tsao \& Tu, 2017). They can even design a roulette game for prizes during check-out so as to give consumers some fun experiences.

The booming development of e-commerce has led to s significant recession in brick-and-mortar channels in recent years (Tsao \& Tseng, 2011; Tsao, 2014; Chinatimes, 2017). However, brick-and-mortar stores still have niches. This study specifically proposed a suggestion regarding strategic management for brick-and-mortar channels. Hedonic experiential values can increase or strengthen consumer loyal to a greater degree than utilitarian experiential values. Aesthetics, for example, is the only of the three hedonic experiential values that can gives brick-and-mortar channels a significant competitive advantage over online channels and the key to preventing brick-and-mortar stores from being replaced by online stores. We suggest using 1. Visual elements that stand out from the environment and 2. Intriguing or dramatic aesthetics (Mathwick et al., 2001). Actual operation strategies can be aimed toward store aesthetics or designs with a unique style. Stores can also coordinate with festivals or other seasonal themes in the décor or product packaging. Providing such feasts for the eyes is currently difficult for online channels. The application of escapism in the design of store environments is also a crucial strategy. Any elements involving the five senses, such as music or the sharing or launch of new books for sound, the fragrance of coffee, essential oils, or books for smell, operating experiences or textured designs for touch, spatial or display aesthetics for sight, and coffee, tea, or desserts for taste, can help with escapism designs, enabling consumers to temporarily extract themselves from their original lives and feel truly relaxed. It is worth noting that the importance of the utilitarian service excellence is significantly more important in offline channels than in online channels. Thus, brick-and-mortar stores can devote more efforts to improving their service quality, develop customized services, and train first-line employees in customer complaint handling and service failure recovery (Tsao, Hsieh, Ye, \& Tsai, 2014). 


\subsection{Limitation and Future Research}

Due to limited resources, this study is not without limitations. First, the questionnaire survey of this study was performed completely on online platforms, which is suitable for collecting data regarding online channels. However, the results may lack representativeness with regard to brick-and-mortar channels. This study therefore suggests that random and representative sampling techniques be used when choosing samples and collecting questionnaires concerning brick-and-mortar channels. Next, the six experiential values in this study come from our literature review and may not cover all of the experiential elements that customers care about. We suggest that qualitative research be conducted for pilot study, which we expect will create greater comprehensiveness in the experiential value factors. It is predicted that flow research can be applied to eWOM and the currently popular live streaming (Tsao, 2014; Tsao et al., 2015). Thus, this study also suggests that future research apply or expand our research framework to explore these emerging fields of research.

\section{References}

Addis, M., \& Sala, G. (2007). Buying a book as a Christmas gift: two routes to customer immersion. The Service Industries Journal, 27(8), 991-1006. https://doi.org/10.1080/02642060701673638

Ahmed, Z. U., Ghingold, M., \& Dahari, Z. (2007). Malaysian shopping mall behavior: an exploratory study. Asia Pacific Journal of Marketing and Logistics, 19(4), 331-348. https://doi.org/10.1108/13555850710827841

American Marketing Association. (2014). Retrieved from https://www.ama.org/resources/Pages/Dictionary.aspx?dLetter=W\#word-of-mouth+communication

Anderson, J. C., \& Gerbing, D. W. (1988). Structural equation modeling in practice: A review and recommended two-step approach. Psychological Bulletin, 103(3), 411. https://doi.org/10.1037/0033-2909.103.3.411

Augustine, S. M., \& Zoss, M. (2006). Aesthetic flow experience in the teaching of preservice language arts teachers. English Education, 39(1), 72-95.

Babin, B. J., Darden, W. R., \& Griffin, M. (1994). Work and/or fun: measuring hedonic and utilitarian shopping value. Journal of Consumer Research, 20(4), 644-656. https://doi.org/10.1086/209376

Bäckström, K., \& Johansson, U. (2006). Creating and consuming experiences in retail store environments: Comparing retailer and consumer perspectives. Journal of Retailing and Consumer Services, 13(6), 417-430. https://doi.org/10.1016/j.jretconser.2006.02.005

Bagozzi, R. P., \& Heatherton, T. F. (1994). A general approach to representing multifaceted personality constructs: Application to state self-esteem. Structural Equation Modeling: A Multidisciplinary Journal, 1(1), 35-67. https://doi.org/10.1080/10705519409539961

Bilgihan, A., Okumus, F., Nusair, K., \& Bujisic, M. (2014). Online experiences: flow theory, measuring online customer experience in e-commerce and managerial implications for the lodging industry. Information Technology \& Tourism, 14(1), 49-71. https://doi.org/10.1007/s40558-013-0003-3

Bridges, E., \& Florsheim, R. (2008). Hedonic and utilitarian shopping goals: The online experience. Journal of Business Research, 61(4), 309-314. https://doi.org/10.1016/j.jbusres.2007.06.017

Broekhuizen, T. L., \& Jager, W. (2004). A conceptual model of channel choice: Measuring online and offline shopping value perceptions. Groningen, University of Groningen.

Calvo-Porral, C., Faíña-Medín, A., \& Nieto-Mengotti, M. (2017). Exploring technology satisfaction: An approach through the flow experience. Computers in Human Behavior, 66, 400-408. https://doi.org/10.1016/j.chb.2016.10.008

Chen, C. F., \& Chen, F. S. (2010). Experience quality, perceived value, satisfaction and behavioral intentions for heritage tourists. Tourism Management, 31(1), 29-35. https://doi.org/10.1016/j.tourman.2009.02.008

Chinatimes. (2017). Brick-and-mortar bookstore is off trending now, 400 has been closed in nine years. Retrieved from https://udn.com/news/story/9994/1802763

Choi, S. (2015). Understanding roles of experiential value and perceived switching drivers on travelers' loyalty: an empirical study of third-party travel websites (Doctoral dissertation, Kansas State University).

Chu, S. Y. C., Wu, C. M., Wu, K. I. F., \& Chen, Y. F. (2016). Does Established Offline Store Drive Online Purchase Intention?. International Journal of Business and Information, 11(4).

Chua, B. L., Jin, N., Lee, S., \& Goh, B. (2014). Influence of Mechanic, Functional, and Humanic Clues on Customers' Experiential Values and Behavioral Intentions in Full-Service Restaurants. Journal of 
Foodservice Business Research, 17(2), 67-84. https://doi.org/10.1080/15378020.2014.902641

Csikszentmihalyi, M. (1975). Beyond Boredom and Anxiety. San Francisco: Jossey-Bass.

Drengner, J., Gaus, H., \& Jahn, S. (2008). Does flow influence the brand image in event marketing?. Journal of Advertising Research, 48(1), 138-147. https://doi.org/10.2501/S0021849908080148

Ducoffe, R. H. (1996). ADVERTISING VALUE AND ADVERTISING THE WEB. Journal of Advertising Research, 36(5), 21-35.

Ebrahim, R., Ghoneim, A., Irani, Z., \& Fan, Y. (2016). A brand preference and repurchase intention model: the role of consumer experience. Journal of Marketing Management, 1-30. https://doi.org/10.1080/0267257X.2016.1150322

Ellis, G. D., \& Rossman, J. R. (2008). Creating Value for Participants through Experience Staging: Parks, Recreation, and Tourism in the Experience Industry. Journal of Park \& Recreation Administration, 26(4).

Fornell, C. (1992). A National Customer Satisfaction Barometer: The Swedish Experience. Journal of Marketing, 56(1), 6-21. https://doi.org/10.2307/1252129

Fornell, C., \& Larcker, D. F. (1981). Evaluating structural equation models with unobservable variables and measurement error. Journal of Marketing Research, 39-50. https://doi.org/10.2307/3151312

Ghani, J. A., \& Deshpande, S. P. (1994). Task characteristics and the experience of optimal flow in humancomputer interaction. The Journal of Psychology, 128(4), 381-391. https://doi.org/10.1080/00223980.1994.9712742

Hair, J. F., Anderson, R. E., Tatham, R. L., \& Black, W. C. (1998). Multivariate data analysis. New Jersey, NJ: Prentice-Hall.

Hausman, A. V., \& Siekpe, J. S. (2009). The effect of web interface features on consumer online purchase intentions. Journal of Business Research, 62(1), 5-13. https://doi.org/10.1016/j.jbusres.2008.01.018

Hicks, J. M., Page Jr, T. J., Behe, B. K., Dennis, J. H., \& Fernandez, R. T. (2005). Delighted consumers buy again. Journal of Consumer Satisfaction, Dissatisfaction and Complaining Behavior, 18, 94.

Holbrook, M. B. (1996). Customer Value-A Framework for Analysis and Research. Advances in Consumer Research, 23(1), 138-142.

Holbrook, M. B. (1978). Beyond Attitude Structure: Toward the Informational Determinants of Attitude. Journal of Marketing Research, 15(4), 545-556. http://dx.doi.org/10.2307/3150624

Hooper, D., Coughlan, J., \& Mullen, M. (2008). Structural Equation Modelling: Guidelines for Determining Model Fit. Electronic Journal of Business Research Methods, 6(1), 53-60.

Houge Mackenzie, S., Son, J. S., \& Hollenhorst, S. (2014). Unifying psychology and experiential education: Toward an integrated understanding of why it works. Journal of Experiential Education, 37(1), 75-88. https://doi.org/10.1177/1053825913518894

Hsu, C. L., Chang, K. C., \& Chen, M. C. (2012). The impact of website quality on customer satisfaction and purchase intention: perceived playfulness and perceived flow as mediators. Information Systems and e-Business Management, 10(4), 549-570. https://doi.org/10.1007/s10257-011-0181-5

Huang, M. H. (2003). Designing website attributes to induce experiential encounters. Computers in Human Behavior, 19(4), 425-442. https://doi.org/10.1016/S0747-5632(02)00080-8

Jin, N., Line, N. D., \& Goh, B. (2013). Experiential value, relationship quality, and customer loyalty in full-service restaurants: The moderating role of gender. Journal of Hospitality Marketing \& Management, 22(7), 679-700. https://doi.org/10.1080/19368623.2013.723799

Keng, C. J., \& Ting, H. Y. (2009). The acceptance of blogs: Using a customer experiential value perspective. Internet Research, 19(5), 479-495. https://doi.org/10.1108/10662240910998850

Keng, C. J., Huang, T. L., Zheng, L. J., \& Hsu, M. K. (2007). Modeling service encounters and customer experiential value in retailing: An empirical investigation of shopping mall customers in Taiwan. International Journal of Service Industry Management, 18(4), 349-367. https://doi.org/10.1108/09564230710778137

Kiili, K. (2005). Content creation challenges and flow experience in educational games: The IT-Emperor case. The Internet and Higher Education, 8(3), 183-198. https://doi.org/10.1016/j.iheduc.2005.06.001 
Kim, S. (2011). Web-interactivity dimensions and shopping experiential value. Journal of Internet Business, (9), 1.

Kim, M., \& Thapa, B. (2017). Perceived value and flow experience: Application in a nature-based tourism context. Journal of Destination Marketing \& Management, in press, http://dx.doi.org/10.1016/j.jdmm.2017.08.002

Koufaris, M. (2002). Applying the technology acceptance model and flow theory to online consumer behavior. Information Systems Research, 13(2), 205-223. https://doi.org/10.1287/isre.13.2.205.83

Kuo, Y. F., Wu, C. M., \& Deng, W. J. (2009). The relationships among service quality, perceived value, customer satisfaction, and post-purchase intention in mobile value-added services. Computers in Human Behavior, 25(4), 887-896. https://doi.org/10.1016/j.chb.2009.03.003

Lambert, E. G., Hogan, N. L., \& Barton, S. M. (2001). The impact of job satisfaction on turnover intent: a test of a structural measurement model using a national sample of workers. The Social Science Journal, 38(2), 233-250. https://doi.org/10.1016/S0362-3319(01)00110-0

Landers, V. M., Beatty, S. E., Wang, S., \& Mothersbaugh, D. L. (2015). The Effect of Online versus Offline Retailer-Brand Image Incongruity on the Flow Experience. Journal of Marketing Theory and Practice, 23(4), 370-387. https://doi.org/10.1080/10696679.2015.1049681

Lankford, E. L. (2002). Aesthetic experience in constructivist museums. Journal of Aesthetic Education, 36(2), 140-153. https://doi.org/10.2307/3333763

Li, G. (2015). The Influence of Interactivity on Experiential Value. Management \& Engineering, (20), 19.

Li, H., Kuo, C., \& Rusell, M. G. (1999). The impact of perceived channel utilities, shopping orientations, and demographics on the consumer's online buying behavior. Journal ogf Computer-Mediated Communication, 5(2), 0-0. https://doi.org/10.1111/j.1083-6101.1999.tb00336.x

Lim, W. M. (2014). Understanding the influence of online flow elements on hedonic and utilitarian online shopping experiences: A case of online group buying. Journal of Information Systems, 28(2), 287-306. https://doi.org/10.2308/isys-50773

Lin, K. M. (2006). An Examination of the Relationship Between Experiential Marketing Strategy and Guests' Leisure Behavior in Taiwan Hot-spring Hotels. United States Sports Academy, Daphne.

Maghnati, F., \& Ling, K. C. (2013). Exploring the relationship between experiential value and usage attitude towards mobile apps among the Smartphone users. International Journal of Business and Management, 8(4), 1. https://doi.org/10.5539/ijbm.v8n4p1

Mathwick, C., Malhotra, N., \& Rigdon, E. (2001). Experiential value: conceptualization, measurement and application in the catalog and Internet shopping environment. Journal of Retailing, 77(1), 39-56. https://doi.org/10.1016/S0022-4359(00)00045-2

Molinari, L. K., Abratt, R., \& Dion, P. (2008). Satisfaction, quality and value and effects on repurchase and positive word-of-mouth behavioral intentions in a B2B services context. Journal of Services Marketing, 22(5), 363-373. https://doi.org/10.1108/08876040810889139

Moon, J. W., \& Kim, Y. G. (2001). Extending the TAM for a World-Wide-Web context. Information \& Management, 38(4), 217-230. https://doi.org/10.1016/S0378-7206(00)00061-6

Nigam, A. (2012). Modeling relationship between experiential marketing, experiential value and purchase intensions in organized quick service chain restaurants shoppers using structural equation modeling approach. Paradigm, 16(1), 70-79. https://doi.org/10.1177/0971890720120108

Novak, T. P., Hoffman, D. L., \& Yung, Y. F. (2000). Measuring the customer experience in online environments: A structural modeling approach. Marketing Science, 19(1), 22-42. https://doi.org/10.1287/mksc.19.1.22.15184

Nunnally, J. C., \& Bernstein, I. H. (1994). Psychometric theory (3rd ed.). New York, NY: McGraw-Hill.

Nusair, K., \& Parsa, H. G. (2011). Introducing flow theory to explain the interactive online shopping experience in a travel context. International Journal of Hospitality \& Tourism Administration, 12(1), 1-20. https://doi.org/10.1080/15256480.2011.540974

O'Cass, A., \& Carlson, J. (2010). Examining the effects of website-induced flow in professional sporting team websites. Internet Research, 20(2), 115-134. https://doi.org/10.1108/10662241011032209 
Overby, J. W., \& Lee, E. J. (2006). The effects of utilitarian and hedonic online shopping value on consumer preference and intentions. Journal of Business Research, 59(10), 1160-1166. https://doi.org/10.1016/j.jbusres.2006.03.008

Park, H., Lim, H., \& Kim, Y. K. (2013). Experiential value: Application to innovative consumer technology $\begin{array}{llllll}\text { products. } & \text { Journal of } & \text { Customer } & \text { Behaviour, } & \text { 12(1), } & \text { 7-24. }\end{array}$ https://doi.org/10.1362/147539213X13645550618443

Park, S. R. (2012). The role of interactivity in internet business on customer experiential values and behavioral intentions. The University of Nebraska-Lincoln.

Pelet, J. É., Ettis, S., \& Cowart, K. (2017). Optimal experience of flow enhanced by telepresence: Evidence from social media use. Information \& Management, 54(1), 115-128. https://doi.org/10.1016/j.im.2016.05.001

Peterson, R. A., Balasubramanian, S., \& Bronnenberg, B. J. (1997). Exploring the implications of the Internet for consumer marketing. Journal of the Academy of Marketing Science, 25(4), 329-346. https://doi.org/10.1177/0092070397254005

Pine, B. J. II., \& Gilmore, J. H. (1998). Welcome to the experience economy. Harvard Business Review, 76(4), 97-105.

Pine, B. J., \& Gilmore, J. H. (1999). The experience economy: work is theatre \& every business a stage. Brighton, Boston: Harvard Business Press.

Rapp, A., Baker, T. L., Bachrach, D. G., Ogilvie, J., \& Beitelspacher, L. S. (2015). Perceived customer showrooming behavior and the effect on retail salesperson self-efficacy and performance. Journal of Retailing, 91(2), 358-369. https://doi.org/10.1016/j.jretai.2014.12.007

Scarpi, D., Pizzi, G., \& Visentin, M. (2014). Shopping for fun or shopping to buy: Is it different online and offline?. Journal of Retailing and Consumer Services, 21(3), 258-267. https://doi.org/10.1016/j.jretconser.2014.02.007

Senecal, S., Gharbi, J. E., \& Nantel, J. (2002). The influence of flow on hedonic and utilitarian shopping values. NA-Advances in Consumer Research, 29.

Shang, R. A., Chen, Y. C., \& Shen, L. (2005). Extrinsic versus intrinsic motivations for consumers to shop on-line. Information \& Management, 42(3), 401-413. https://doi.org/10.1016/j.im.2004.01.009

Shellman, A. (2014). Empowerment and experiential education: A state of knowledge paper. Journal of Experiential Education, 37(1), 18-30. https://doi.org/10.1177/1053825913518896

Shobeiri, S., Mazaheri, E., \& Laroche, M. (2014). Improving customer website involvement through experiential marketing. The Service Industries Journal, 34(11), 885-900. https://doi.org/10.1080/02642069.2014.915953

Shyu, C. S., \& Chou, M. J. (2015). WHOSE AESTHETICS WORLD? EXPLORATION OF AESTHETICS CULTIVATION FROM THE CHILDREN'S OUTDOOR PLAYGROUND EXPERIENTIAL VALUE PERSPECTIVE. International Journal of Organizational Innovation (Online), 8(2), 158.

Simonin, B. L. (1999). Transfer of Marketing Know-How in International Strategic Alliances: An Empirical Investigation of the Role and Antecedents of Knowledge Ambiguity. Journal of International Business Studies, 30(3), 463-490. https://doi.org/10.1057/palgrave.jibs.8490079

Söderlund, M. (1998). Customer satisfaction and its consequences on customer behaviour revisited: The impact of different levels of satisfaction on word-of-mouth, feedback to the supplier and loyalty. International Journal of Service Industry Management, 9(2), 169-188. https://doi.org/10.1108/09564239810210532

Staelens, N., Moens, S., Van den Broeck, W., Marien, I., Vermeulen, B., Lambert, P., ... Demeester, P. (2010). Assessing quality of experience of IPTV and video on demand services in real-life environments. IEEE Transactions on Broadcasting, 56(4), 458-466. https://doi.org/10.1109/TBC.2010.2067710

Theodorakis, N. D., Koustelios, A., Robinson, L., \& Barlas, A. (2009). Moderating role of team identification on the relationship between service quality and repurchase intentions among spectators of professional sports. Managing Service Quality: An International Journal, 19(4), 456-473. https://doi.org/10.1108/09604520910971557

Trevino, L. K., \& Webster, J. (1992). Flow in computer-mediated communication: Electronic mail and voice mail evaluation and impacts. Communication Research, 19(5), 539-573. https://doi.org/10.1177/009365092019005001 
Tsao, W. C. (2014). Exploring Routes to Persuasive Online Advertising. International Journal of Business and Management, 9(12), 35-48. https://doi.org/10.5539/ijbm.v9n12p35

Tsao, W. C., \& Chen, Y. H. (2011). A study of the impact and application of cause-corporate brand alliance on Taiwan's tourist amusement industry. African Journal of Business Management, 5(2), 316-331.

Tsao, W. C., \& Hsieh, M. T. (2015). eWOM persuasiveness: do eWOM platforms and product type matter?. Electronic Commerce Research Journal, 15(4), 509-541. https://doi.org/10.1007/s10660-015-9198-z

Tsao, W. C., \& Tseng, Y. L. (2011). The impact of electronic-service quality on online shopping behaviour. Total Quality Management \& Business Excellence, 22(9), 1007-1024. https://doi.org/10.1080/14783363.2011.593869

Tsao, W. C., \& Tu, Y. H. (2017). Presentation of QR Code on Product Packages: Information Content from the Perspective of Cognitive Fit Theory. International Review of Management and Business Research, 6(3), 1137-1150.

Tsao, W. C., \& Yang, F. J. (2017). Factors that Influence the Intention to Use Mobile Shopping Platforms Which Feature Virtual Shelves and QR Codes -Based on TAM. International Review of Management and Business Research, 6(2), 758-776.

Tsao, W. C., Hsieh, M. T., Shih, L. W., \& Lin, T. M. (2015). Compliance with eWOM: The influence of hotel reviews on booking intention from the perspective of consumer conformity. International Journal of Hospitality Management, 46, 99-111. https://doi.org/10.1016/j.ijhm.2015.01.008

Tsao, W. C., Hsieh, M. T., Ye, J. S. \& Tsai, C. H. (2014). Loyalty or defection? An Application of equity theory on service recovery in Hospitality Industry: A star rating perspective. Conference on Sustainable Operation and Development Technology Innovation and Management in a Global Era, LIM007.

Tynan, C., McKechnie, S., \& Hartley, S. (2014). Interpreting value in the customer service experience using customer-dominant logic. Journal of Marketing Management, 30(9-10), 1058-1081. https://doi.org/10.1080/0267257X.2014.934269

Unger, L. S., \& Kernan, J. B. (1983). On the Meaning of Leisure: An Investigation of Some Determinants of the Subjective Experience. Journal of Consumer Research, 9(4), 381-392. https://doi.org/10.1086/208932

United Daily. (2016). No match for online shopping, physical retailing has closed unprecedently. Retrieved from http://www.chinatimes.com/newspapers/20170425000066-260203

Van Noort, G., Voorveld, H. A. M., \& van Reijmersdal, E. A. (2012). Interactivity in Brand Web Sites: Cognitive, Affective, and Behavioral Responses Explained by Consumers' Online Flow Experience. Journal of Interactive Marketing, 26, 223-234. https://doi.org/10.1016/j.intmar.2011.11.002

Verhagen, T., \& Van Dolen, W. (2009). Online purchase intentions: A multi-channel store image perspective. Information \& Management, 46(2), 77-82. https://doi.org/10.1016/j.im.2008.12.001

Verhagen, T., Feldberg, F., van den Hooff, B., Meents, S., \& Merikivi, J. (2011). Satisfaction with virtual worlds: An integrated model of experiential value. Information \& Management, 48(6), 201-207. https://doi.org/10.1016/j.im.2011.02.004

Wang, L. C., \& Hsiao, D. F. (2012). Antecedents of flow in retail store shopping. Journal of Retailing and Consumer Services, 19(4), 381-389. https://doi.org/10.1016/j.jretconser.2012.03.002

Wang, L. C., Baker, J., Wagner, J. A., \& Wakefield, K. (2007). Can a retail web site be social?. Journal of Marketing, 71(3), 143-157. https://doi.org/10.1509/jmkg.71.3.143

Wang, Y. B., Ho, C. W., \& Chen, T. (2015). Does sense of virtual community and experience marketing increase the purchase intention of cultural and creative illustration products?. In Ubi-Media Computing (UMEDIA), 2015 8th International Conference on (pp. 350-354). IEEE. https://doi.org/10.1109/UMEDIA.2015.7297484

Williams, A. (2006). Tourism and hospitality marketing: Fantasy, feeling and fun. International Journal of Contemporary Hospitality Management, 18(6), 482-495. https://doi.org/10.1108/09596110610681520

Wirtz, J., \& Chew, P. (2002). The effects of incentives, deal proneness, satisfaction and tie strength on word-of-mouth behaviour. International Journal of Service Industry Management, 13(2), 141-162. https://doi.org/10.1108/09564230210425340

Wu, C. H. J., \& Liang, R. D. (2009). Effect of experiential value on customer satisfaction with service 
encounters in luxury-hotel restaurants. International Journal of Hospitality Management, 28(4), 586-593. https://doi.org/10.1016/j.ijhm.2009.03.008

Zhou, T., \& Lu, Y. (2011). Examining mobile instant messaging user loyalty from the perspectives of network externalities and flow experience. Computers in Human Behavior, 27(2), 883-889. https://doi.org/10.1016/j.chb.2010.11.013

\section{Appendix A. Measurement Instruments}

This appendix contains the statements used in the survey. Respondents were asked to what degree they agree or disagree with these statements on a seven-point Likert scale.

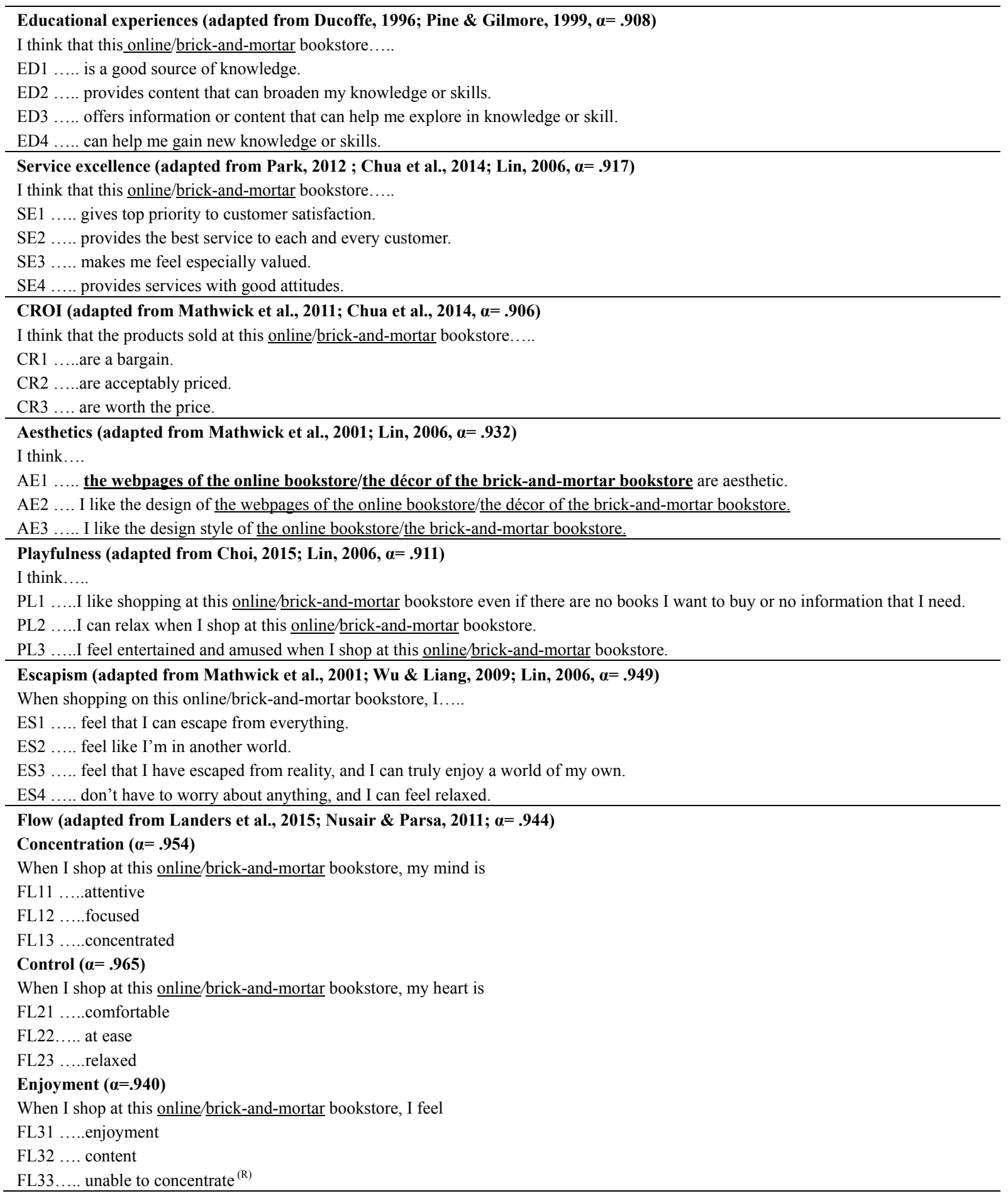


Repurchase intention (adapted from Theodorakis et al., 2009; Hicks et al., 2005, $\alpha=.941$ )

I think....

$\mathrm{RP} 1$..... this online/brick-and-mortar bookstore is my first choice for shopping

RP2 .....it is highly likely that I will buy something from this online/brick-and-mortar bookstore again in the future.

Positive WOM (adapted from Molinari et al., 2008, $\alpha=.943$ )

I would.....

PW1.....strongly recommend this online/brick-and-mortar bookstore to other people.

PW2.....encourage other people to buy things from this online/brick-and-mortar bookstore.

PW3.....share things that are favourable to this online/brick-and-mortar bookstore with other people.

\section{Copyrights}

Copyright for this article is retained by the author, with first publication rights granted to the journal.

This is an open-access article distributed under the terms and conditions of the Creative Commons Attribution license (http://creativecommons.org/licenses/by/4.0/). 